\title{
Epidemiological analysis of Nosocomial Candida infections: Experience of a university hospital
}

\section{Nozokomiyal Kandida enfeksiyonlarının epidemiyolojik analizi: Bir üniversite hastanesi deneyimi}

\author{
Seyit Ali Büyüktuna', Mürşit Hasbek², Nazif Elaldı", Mustafa Gökhan Gözel' ${ }^{3}$, Cem Çelik², Aynur

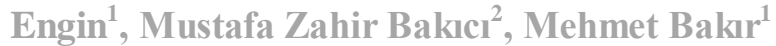

\begin{abstract}
Department of Infectious Diseases and Clinical Microbiology, Faculty of Medicine, Cumhuriyet University, Sivas, Turkey
${ }^{2}$ Department of Medical Microbiology, Faculty of Medicine, Cumhuriyet University, Sivas, Turkey

${ }^{3}$ Department of Communicable Diseases, General Directorate of Public Health, Ministry of Health, Ankara, Turkey

Corresponding author: Seyit Ali Büyüktuna, MD, Department of Infectious Diseases and Clinical Microbiology, Faculty of Medicine, Cumhuriyet

University, Sivas, Turkey

E-mail: alibuyuktuna@gmail.com

Received/Accepted: April 12, 2019 / June 12, 2019

Conflict of interest: There is not a conflict of interest.
\end{abstract}

\section{SUMMARY}

Objective: A retrospective investigation was made in a university hospital setting of the distribution of Candida infections in terms of species, different clinical features of infections, risk factors for candidemia caused by these fungi and their antifungal susceptibilities.

Method: This study was conducted between January ${ }^{15 t,}$ 2014, and December 31st, 2017. Patients included in the study were those diagnosed with candida infection as a result of Candida species, isolated from at least one clinical sample of those taken from hospitalized patients, including blood, urine, and other clinical samples, and who were then administered antifungal therapy. The identification of Candida species was performed using Matrix-Assisted Laser Desorption/Ionization Time-of-Mass Spectrometry (MALDI-TOF MS).

Results: During the study period, the candida infection rate was found to be $5.86 \%$ in the 2760 episodes of infection, and the incidence of candida infection was found to be 0.35 in 1000 bed days. The most common infection site for candida was the urinary tract $(61.1 \%)$, followed by the blood-stream (31.5\%). In $66 \%$ of all candida infections, Candida albicans was defined as the causative agent. The distribution of Candida glabrata, Candida tropicalis, Candida parapsilosis, Candida lusiteniae, Candida krusei, and Candida kefyr were determined as 9.9\%, 9.3\%, 4.9\%, 2.5\%, 1.9\% and 1.2\%, respectively. The sensitivity to fluconazole and amphotericin B was determined as $97.2 \%$ and $99.1 \%$ in the C. albicans isolates, respectively. The sensitivity ratios for both fluconazole and amphotericin B were determined as $78.2 \%$ in the non-albicans strains. Multivariate logistic regression analysis showed that total parenteral nutrition (TPN) [Odds ratio (OR) 3.69, 95\% Confidence interval, 1.595-8.570; $\mathrm{p}=0.002$ ] was an independent risk factor for candidemia in patients with Candida infection.

Conclusions: $C$. albicans was the most encountered species in candida infections in our hospital. TPN was determined as an independent risk factor for the development of candidemia. Determinations of the species distribution of fungal infections and the antifungal sensitivity are important for the selection of effective treatment.

Keywords: Candida infection, clinical features, risk factors for candidemia

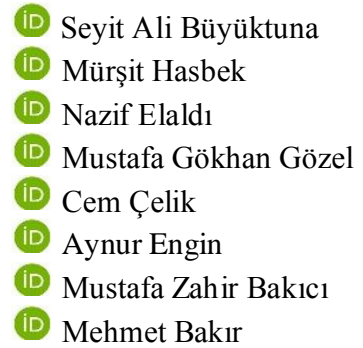

ORCID IDs of the authors:

S.A.B. $0000-0001-6518-7361$

M.H. 0000-0002-5217-8607

N.E. 0000-0002-9515-770X

M.G.G.0000-0001-5187-7388

C.Ç. 0000-0002-7141-5874

A.E. $0000-0002-8533-8793$

M.Z.B. 0000-0003-3823-0007

M.B. 0000-0003-3702-1932 
Amaç: Bu çalışmada retrospektif olarak bir üniversite hastanesindeki kandida enfeksiyonlarının etken bazında dağılımı, bu etkenlerin yol açtığı enfeksiyonların farklı klinik özelliklerinin ve kandidemi için risk faktörlerinin belirlenmesi ve etken kandidaların antifungal duyarlılıklarının saptanması amaçlanmıştır.

Yöntem: Çalışma 01 Ocak 2014 - 31 Aralık 2017 tarihleri arasında gerçekleştirilmiştir. Hastaneye yatırılarak takip edilen hastalardan alınan kan, idrar ve diğer vücut örneklerinden en az birinde kandida üremesi kandida enfeksiyonu olgusu olarak değerlendirilmiş ve antifungal tedavi verilen olgular değerlendirmeye alınmıştır. İzolatların tanımlanması Matrix-Assisted Laser Desorption/Ionization Time-of-Mass Spectrometry (MALDI-TOF-MS) sistemi kullanılarak yapılmıştır.

Bulgular: Çalışma süresi içinde toplam 2760 enfeksiyon epizodunda kandida enfeksiyon hızı \%5.86, kandida enfeksiyonu insidans dansitesi ise 1000 yatak gününe 0.35 olarak bulunmuştur. En sık saptanan kandida enfeksiyonu üriner sistem enfeksiyonu olup (\%61.1), bunu \%31.5 ile kandidemi takip etmiştir. Tüm kandida enfeksiyonlarının \%66'sında Candida albicans etken olarak tanımlanmıștır. Bunu \%9.9 ile Candida glabrata, \% 9.3 ile Candida tropicalis, \%4.9 ile Candida parapsilosis, \%2.5 ile Candida lusiteniae, \%1.9 ile Candida krusei ve \%1.2 ile Candida kefyr takip etmiştir. Saptanan C. albicans izolatlarında flukonazol duyarlılığı \%97.2, amphotericin B duyarlılığı ise \%99.1 olarak bulunmuştur. Non-albicans kandida suşlarında ise flukonazol ve amfoterisin B duyarlılığı \%78.2 olarak saptanmıştır. Çoklu regresyon analizinde total parenteral nütrisyon (TPN) uygulamasının [Odds ratio (OR) 3.69, \%95 Güvenlik Aralığı (\%95 GA) 1.595-8.570; P=0.002] kandidemi için bağımsız risk faktörü olduğu gözlenmiştir.

Sonuç: Hastanemizde ortaya çıkan kandida enfeksiyonlarında C. albicans suşları ön plandadır. Kandidemi gelişiminde total parenteral nütrisyon kullanımı bağımsız bir risk faktörü olarak görülmektedir. Hastanelerde fungal enfeksiyon etkenlerinin dağılımlarının ve antifungal duyarlılıklarının bilinmesi effektif tedavi seçiminde önemlidir.

Anahtar sözcükler: Kandida enfeksiyonu, klinik özellikler, kandidemi için risk faktörleri

\section{INTRODUCTION}

Candida species, which are fungi morphology that can produce true or false hyphae, can cause diseases ranging from local mucosal infections to invasive fungal infections in humans ${ }^{1}$. Candida species are the most common cause of opportunistic fungal infections and account for approximately $70-90 \%$ of invasive fungal infections $^{2}$. The incidence and prevalence of invasive fungal infections have increased since the 1980 s, especially in the vast majority of immunocompromised patients and / or in hospitalized patients with severe underlying diseases $^{3,4}$.

More than 15 different subtypes of Candida species are known to be etiological agents in human infections. However, more than $90 \%$ of invasive infections are caused by Candida albicans, Candida glabrata, Candida tropicalis, Candida parapsilosis, and Candida krusei ${ }^{5}$. Over the past two decades, non-albicans species have gained medical importance, and isolation frequency has increased in microbiological specimens ${ }^{6}$.

The increase in the frequency of healthcarerelated infections associated with Candida species is more commonly involved in patients with immunosuppression and using broad-spectrum antibiotics. Furthermore, the role of hospital staff and the contaminated material used the management of a patient in the emergence of Candida infections in critical patient care units such as intensive care has been demonstrated by molecular methods ${ }^{7}$.

The timely administration of appropriate antimicrobial treatment is crucial in patients with specified clinical conditions. Thus, the determination of the distribution of fungal infections and considering the antifungal susceptibility of etiological agents are important. Late diagnosis of candida infections or late initiation of antifungal therapy may lead to high mortality rates in the units where serious cases are treated, such as intensive care units and hematology-oncology units. The aim of this study was to investigate the distribution of nosocomial Candida infections in our hospital and to determine the antifungal sensitivities of these infections.

\section{MATERIAL AND METHODS}

This study was conducted between January 1st, 2014 and December ${ }^{31 s t,}$ 2017. Retrospective data were obtained from the patient and laboratorybased surveillance records. Identification of nosocomial infections was performed according to the diagnostic criteria determined by the United States Centers for Diseases Control and Prevention $(\mathrm{CDC})^{8}$. The patients included in the study were those with Candida species, isolated from at least one of clinical samples including blood, urine, abscesses and endoscopic esophageal biopsy specimens taken from hospitalized patients, which was then considered as a case of candida infection and antifungal 
therapy was administered. Cases were excluded if Candida growth in clinical samples was evaluated as colonization, and no antifungal treatment was given. The first fungal agent isolated from a patient was included in the study, recurrent isolates of the same patient were not included. Clinical samples other than the blood sample sent from patients were planted on 5\% sheep blood agar and Eosin-Methylene-Blue (EMB) agar. Blood samples were cultured in blood culture bottles (Bactec FX-Becton Dickinson ${ }^{\circledR}$, Maryland / USA) and incubated at $37^{\circ} \mathrm{C}$ in the incubator. Samples of Candida type fungi were also implanted in Sabouraud dextrose agar (SDA) medium. Germ tube tests were conducted on the produced candida strains. Isolates were defined using Matrix-Assisted Laser Desorption/Ionization Time-of-Mass Spectrometry (MALDI-TOF MS) based on the Bruker IVD MALDI Biotyper 2.3 (Bruker Daltonik GmbH, Bremen, Germany) device. The system gives a score of $0-3$ according to the measurement results. According to the manufacturer's guide, (Bruker Daltonics, Germany) values $<, 1.7$ do not pass the reliability level, scores between 1.7-2.0 are reliable definitions of type basis, and scores between 2.03.0 are reliable definitions of both type and species basis. In the present study, evaluations were made of the results of fungal definitions of 155 strains $(95.7 \%)$ identified at the species level, of $\geq 2.0,7$ isolates $(4.3 \%)$ were identified at the genus level and 1.7-2.0 reliability scores were obtained. Antifungal sensitivity tests for amphotericin B, fluconazole, and itraconazole were applied using the colorimetric liquid microdilution method (TREK DiagnosticSensititre ${ }^{\circledR}$ al Yeastone ${ }^{\circledR}$, West Sussex, UK). Approval for the study was obtained from the Local Ethics Committee (decision no: 201804/36).

\section{Statistical analysis:}

Data obtained in this descriptive study were analyzed using SPSS version 15.0 (SPSS, Inc,
Chicago, IL, USA). Results were shown as the mean \pm standard deviation for continuous variables, and the number of cases and percentage (\%) for nominal variables. Categorical variables were evaluated using the $\chi 2$ test. Univariate analysis was performed by determining the independent variables for the logistic model formed in order to determine the characteristics that affect the development of candidemia in patients with Candida infection. In this analysis, variables with $p$-value $<0.1$ were analyzed using backward logistic regression analysis; the Odds ratio (OR) and 95\% confidence interval $(95 \% \mathrm{CI})$ were determined. A value of $\mathrm{p}<0.05$ was considered statistically significant.

\section{RESULTS}

The study was included a total of 162 patients who developed candida infection during the defined 4-year period. The patients comprised $53.1 \%$ females and $46.9 \%$ males with a mean age of $66 \pm 16$ years (range: $18-92$ years). Of the total 162 patients with candida infection, $37 \%$ were hospitalized in the anesthesiology intensive care unit. The demographic characteristics of the patients are shown in Table 1.

The rate of candida infection was determined to be $5.86 \%$, and the incidence rate of candida infection was 0.35 per 1000 beds in a total of 2760 infection episodes that occurred between 2014 and 2017 years (Table 2).

The most common candida infection in this process was urinary tract infection (UTI) $(61.1 \%)$, followed by candidemia at $31.5 \%$. The incidence of candidemia was 0.11 per 1000 patient days. The agent was determined to be $C$. albicans in $66 \%$, followed by C. glabrata, C. tropicalis, $C$. parapsilosis, C. lusiteniae, C. krusei, and C. kefyr at $9.9 \%, 9.3 \%, 4.9 \%, 2.5 \%, 1.9 \%$ and $1.2 \%$, respectively. The remaining $4.3 \%$ could not be identified on the basis of type (Table 3 ). 
Table 1: Demographic features and concomitant situations

\begin{tabular}{|l|c|}
\hline Variables & $\mathbf{N}(\boldsymbol{\%})$ \\
\hline Gender & $86(53.1)$ \\
\hline Female & $76(46.9)$ \\
\hline Male & $60(37)$ \\
\hline Hospitalized Department & \\
\hline Anesthesiology and Intensive Care & $32(19.8)$ \\
\hline Unit & $31(19.1)$ \\
\hline Hematology-Oncology & $18(11.1)$ \\
\hline Internal Medicine & $7(4.3)$ \\
\hline General Surgery Intensive Care Unit & $4(2.5)$ \\
\hline Neurology & $4(2.5)$ \\
\hline Neurosurgery Intensive Care Unit & $2(1.2)$ \\
\hline Urology & $1(0.6)$ \\
\hline Burn Unit & $2(1.2)$ \\
\hline Gynecology and Obstetrics & $1(0.6)$ \\
\hline Cardiology & \\
\hline Cardiovascular Surgery & $54(33.3)$ \\
\hline Clinical Diagnosis & $36(22.2)$ \\
\hline Shortness of Breath & $18(11.1)$ \\
\hline Malignancy & $11(6.8)$ \\
\hline Intraabdominal Disease & $11(6.8)$ \\
\hline Cerebrovascular Disease & $7(4.3)$ \\
\hline Renal Disease & $6(3.7)$ \\
\hline Trauma & $19(11.8)$ \\
\hline Sepsis & \\
\hline Others $*$ & $63(38.9)$ \\
\hline Concomitant Situations & $44(27.2)$ \\
\hline Malignancy & $38(23.5)$ \\
\hline Hypertension & $31(19.1)$ \\
\hline Diabetes Mellitus & $26(16.0)$ \\
\hline Chronic Obstructive Pulmonary & $13(8.0)$ \\
\hline Disease & $8(4.9)$ \\
\hline Cerebrovascular Disease & $17(10.5)$ \\
\hline Coronary Artery Disease & $5(3.1)$ \\
\hline Heart Failure & \\
\hline Chronic Renal Failure & \\
\hline Trauma & \\
\hline & \\
\hline & \\
\hline & \\
\hline & \\
\hline
\end{tabular}

*Others (number; \%): Pulmonary thromboembolia $(2 ; 1.2 \%)$, Gastrointestinal hemorrhage $(4 ; 2.5 \%)$, Fournier gangrene $(2 ; 1.2 \%)$, Diabetic ketoacidosis $(3 ; 1.9 \%)$, Coroner artery disease $(2 ; 1.2 \%)$, Burn $(2 ; 1.2 \%)$, Aort aneurysm (1; $0.7 \%)$, Silicosis (1;\% 0.7), Anemia $(2 ; \% 1,2)$

Table 2: Candida infection rate and incidence density according to years

\begin{tabular}{|c|c|c|c|}
\hline Year & Patient Days & $\begin{array}{c}\text { Candida Infection } \\
\text { Rate* }\end{array}$ & $\begin{array}{c}\text { Candida Infection } \\
\text { Incidence Density } * *\end{array}$ \\
\hline $\mathbf{2 0 1 4}$ & 116278 & 3.8 & 0.23 \\
\hline $\mathbf{2 0 1 5}$ & 116738 & 7.1 & 0.37 \\
\hline $\mathbf{2 0 1 6}$ & 110405 & 8.8 & 0.52 \\
\hline $\mathbf{2 0 1 7}$ & 117473 & 4.3 & 0.29 \\
\hline Total & $\mathbf{4 6 0 8 9 4}$ & $\mathbf{5 . 8 6}$ & $\mathbf{0 . 3 5}$ \\
\hline
\end{tabular}

*Candida Hospital Infection Rate: Candida infection count/total infections x 100

**Candida Infection Incidence Density: Candida infections count/duration of hospitalization (days) x 1000 
Table 3: Distribution of Candida species according to years

\begin{tabular}{|c|c|c|c|c|c|}
\hline \multirow[b]{2}{*}{ Candida species } & \multicolumn{4}{|c|}{ Years } & \\
\hline & 2014 & 2015 & 2016 & 2017 & $\begin{array}{c}\text { Total } \\
\mathbf{N}(\%) \\
\end{array}$ \\
\hline Candida albicans & 21 & 32 & 30 & 24 & $107(66.0)$ \\
\hline Candida tropicalis & - & 5 & 7 & 3 & $15(9.3)$ \\
\hline Candida krusei & - & - & 2 & 1 & $3(1.9)$ \\
\hline Candida parapsilosis & - & - & 8 & - & $8(4.9)$ \\
\hline Candida lusiteniae & - & 1 & 3 & - & $4(2.5)$ \\
\hline Candida glabrata & 2 & 2 & 6 & 6 & $16(9.9)$ \\
\hline Candida kefyr & - & 2 & - & - & $2(1.2)$ \\
\hline Candida spp & 4 & 1 & 2 & - & $7(4.3)$ \\
\hline TOTAL & 27 & 43 & 58 & 34 & $162(100)$ \\
\hline
\end{tabular}

The sensitivities to fluconazole and amphotericin B were found as $97.2 \%$, and $99.1 \%$ in C. albicans isolates, respectively. In the non-albicans candida strains, the sensitivity to both fluconazole and amphotericin B was found to be $78.2 \%$. The antifungal susceptibilities of all factors were shown in Table 4.

Table 4: Antifungal susceptibilities of Candida species

\begin{tabular}{|c|c|c|c|c|c|c|c|c|c|}
\hline \multirow[b]{3}{*}{ Species } & \multirow{2}{*}{\multicolumn{3}{|c|}{ Fluconasole }} & \multirow{2}{*}{\multicolumn{3}{|c|}{$\begin{array}{c}\text { Antifungal agents } \\
\text { Itraconasole }\end{array}$}} & & & \\
\hline & & & & & & & \multicolumn{3}{|c|}{ Amphotericin B } \\
\hline & $\mathrm{S}$ & I & $\mathrm{R}$ & $\mathrm{S}$ & I & $\mathrm{R}$ & S & I & $\mathrm{R}$ \\
\hline $\begin{array}{l}\text { C.albicans } \\
(\mathrm{n}=107)(\%)\end{array}$ & $\begin{array}{c}104 \\
(97.2)\end{array}$ & $\begin{array}{c}2 \\
(1.9)\end{array}$ & $\begin{array}{c}1 \\
(0.9)\end{array}$ & $\begin{array}{c}84 \\
(78.5)\end{array}$ & $\begin{array}{c}21 \\
(19.6)\end{array}$ & $\begin{array}{c}2 \\
(1.9)\end{array}$ & $\begin{array}{c}106 \\
(99.1)\end{array}$ & $\begin{array}{c}\mathbf{0} \\
(\mathbf{0})\end{array}$ & $\begin{array}{c}1 \\
(0.9)\end{array}$ \\
\hline $\begin{array}{c}\text { Non-albicans } \\
\text { Candida } \\
(n=55)(\%)\end{array}$ & $\begin{array}{c}43 \\
(78.2)\end{array}$ & $\begin{array}{c}5 \\
(9.1)\end{array}$ & $\begin{array}{c}7 \\
(12.7)\end{array}$ & $\begin{array}{c}20 \\
(36.4)\end{array}$ & $\begin{array}{c}24 \\
(43.6)\end{array}$ & $\begin{array}{c}11 \\
(20)\end{array}$ & $\begin{array}{c}43 \\
(78.2)\end{array}$ & $\begin{array}{c}6 \\
(10.9)\end{array}$ & $\begin{array}{c}6 \\
(10.9)\end{array}$ \\
\hline $\begin{array}{r}\text { C.tropicalis } \\
(\mathrm{n}=15)(\%)\end{array}$ & $\begin{array}{c}9 \\
(60)\end{array}$ & $\begin{array}{c}4 \\
(26.7)\end{array}$ & $\begin{array}{c}2 \\
(13.3)\end{array}$ & $\begin{array}{c}4 \\
(26.7)\end{array}$ & $\begin{array}{c}6 \\
(40)\end{array}$ & $\begin{array}{c}5 \\
(33.3)\end{array}$ & $\begin{array}{c}7 \\
(46.7)\end{array}$ & $\begin{array}{c}3 \\
(20)\end{array}$ & $\begin{array}{c}5 \\
(33.3)\end{array}$ \\
\hline $\begin{array}{l}\text { C.glabrata } \\
(\mathrm{n}=16)(\%)\end{array}$ & $\begin{array}{c}13 \\
(81.2)\end{array}$ & $\begin{array}{c}1 \\
(6.3)\end{array}$ & $\begin{array}{c}2 \\
(12.5)\end{array}$ & $\begin{array}{c}6 \\
(37.5)\end{array}$ & $\begin{array}{c}8 \\
(50)\end{array}$ & $\begin{array}{c}2 \\
(12.5)\end{array}$ & $\begin{array}{c}15 \\
(93.7)\end{array}$ & $\begin{array}{c}1 \\
(6.3)\end{array}$ & $\begin{array}{c}0 \\
(0)\end{array}$ \\
\hline $\begin{array}{r}\text { C.parapsilosis } \\
(\mathrm{n}=8)(\%)\end{array}$ & $\begin{array}{c}8 \\
(100)\end{array}$ & $\begin{array}{c}0 \\
(0)\end{array}$ & $\begin{array}{c}0 \\
(0)\end{array}$ & $\begin{array}{c}0 \\
(0)\end{array}$ & $\begin{array}{c}7 \\
(87.5)\end{array}$ & $\begin{array}{c}1 \\
(12.5)\end{array}$ & $\begin{array}{c}7 \\
(87.5)\end{array}$ & $\begin{array}{c}1 \\
(12.5)\end{array}$ & $\begin{array}{c}0 \\
(0)\end{array}$ \\
\hline $\begin{array}{r}\text { C.lusiteniae } \\
(\mathrm{n}=4)(\%)\end{array}$ & $\begin{array}{c}4 \\
(100)\end{array}$ & $\begin{array}{c}0 \\
(0)\end{array}$ & $\begin{array}{c}0 \\
(0)\end{array}$ & $\begin{array}{c}1 \\
(25)\end{array}$ & $\begin{array}{c}3 \\
(75)\end{array}$ & $\begin{array}{c}0 \\
(0)\end{array}$ & $\begin{array}{c}3 \\
(75)\end{array}$ & $\begin{array}{c}1 \\
(25)\end{array}$ & $\begin{array}{c}0 \\
(0)\end{array}$ \\
\hline $\begin{array}{r}\text { C.krusei } \\
(\mathrm{n}=3)(\%)\end{array}$ & $\begin{array}{c}0 \\
(0)\end{array}$ & $\begin{array}{c}0 \\
(0)\end{array}$ & $\begin{array}{c}3 \\
(100)\end{array}$ & $\begin{array}{c}0 \\
(0)\end{array}$ & $\begin{array}{c}0 \\
(0)\end{array}$ & $\begin{array}{c}3 \\
(100)\end{array}$ & $\begin{array}{c}3 \\
(100)\end{array}$ & $\begin{array}{c}0 \\
(0)\end{array}$ & $\begin{array}{c}0 \\
(0)\end{array}$ \\
\hline $\begin{array}{r}\text { C. kefyr } \\
(\mathrm{n}=2)(\%)\end{array}$ & $\begin{array}{c}2 \\
(100)\end{array}$ & $\begin{array}{c}0 \\
(0)\end{array}$ & $\begin{array}{c}0 \\
(0)\end{array}$ & $\begin{array}{c}2 \\
(100)\end{array}$ & $\begin{array}{c}0 \\
(0)\end{array}$ & $\begin{array}{c}0 \\
(0)\end{array}$ & $\begin{array}{c}1 \\
(50)\end{array}$ & $\begin{array}{c}0 \\
(0)\end{array}$ & $\begin{array}{c}1 \\
(50)\end{array}$ \\
\hline $\begin{array}{r}\text { Candida spp } \\
(\mathrm{n}=7)(\%)\end{array}$ & $\begin{array}{c}7 \\
(100)\end{array}$ & $\begin{array}{c}0 \\
(0)\end{array}$ & $\begin{array}{c}0 \\
(0)\end{array}$ & $\begin{array}{c}7 \\
(100)\end{array}$ & $\begin{array}{c}0 \\
(0)\end{array}$ & $\begin{array}{c}0 \\
(0)\end{array}$ & $\begin{array}{c}7 \\
(100)\end{array}$ & $\begin{array}{c}0 \\
(0)\end{array}$ & $\begin{array}{c}0 \\
(0)\end{array}$ \\
\hline $\begin{array}{c}\text { Total } \\
(\mathrm{n}=162) \\
(\%)\end{array}$ & $\begin{array}{c}147 \\
(90.7)\end{array}$ & $\begin{array}{c}7 \\
(4.4)\end{array}$ & $\begin{array}{c}8 \\
(4.9)\end{array}$ & $\begin{array}{c}104 \\
(64.2)\end{array}$ & $\begin{array}{c}45 \\
(27.8)\end{array}$ & $\begin{array}{l}13 \\
(8)\end{array}$ & $\begin{array}{c}149 \\
(91.9)\end{array}$ & $\begin{array}{c}6 \\
(3.7)\end{array}$ & $\begin{array}{c}7 \\
(4.4)\end{array}$ \\
\hline
\end{tabular}

S: Sensitive, I: Intermediate, R: Resistant 
The use of total parenteral nutrition (TPN), blood transfusion, cerebrovascular disease, heart failure, male gender, presence of surgical drainage tubes, nasogastric tube, intubation, and previous macrolide use were found to be associated with the development of candidemia.

In multivariate logistic regression analysis, the application of TPN [Odds ratio (OR) 3.69, 95\%
CI $(1.5 \% \mathrm{CI}) 1.595-8.570 ; \mathrm{P}=0.002]$ was found to be an independent risk factor for the development of candidemia and to increase the risk 3.69-fold. The univariate analysis results for risk factors facilitating the development of candidemia in patients with Candida infection are shown in Table 5, and the multivariate logistic regression analysis results are shown in Table 6.

Table 5: Association of risk factors of cases developing candidemia (Univariate analysis results)*

\begin{tabular}{|c|c|c|c|}
\hline Variables & $\begin{array}{c}\text { Patients Not } \\
\text { Developing } \\
\text { Candidemia } \\
(n=111)\end{array}$ & $\begin{array}{c}\text { Patients } \\
\text { Developing } \\
\text { Candidemia } \\
(\mathbf{n}=51)\end{array}$ & p-value \\
\hline Age & & & 0.180 \\
\hline$<65$ years & $42(37.8)$ & $25(49)$ & \\
\hline$\geq 65$ years & $69(62.2)$ & $26(51)$ & \\
\hline \multicolumn{4}{|l|}{ Gender } \\
\hline Female & $64(57.7)$ & $22(43.1)$ & \\
\hline Male & $47(42.3)$ & $29(56.9)$ & $\mathbf{0 . 0 8 5}$ \\
\hline \multicolumn{4}{|l|}{ Invasive Device } \\
\hline Drainage Tube & $24(21.6)$ & $18(35.3)$ & 0.065 \\
\hline Intubation & $54(48.6)$ & $17(33.3)$ & 0.068 \\
\hline Chest tube & $10(9.0)$ & $8(15.7)$ & 0.209 \\
\hline Urinary catheter & $97(87.3)$ & $40(78.4)$ & 0.143 \\
\hline Mechanical ventilation & $54(48.6)$ & $18(35.3)$ & 0.112 \\
\hline Central venous catheter & $68(61.3)$ & $34(66.7)$ & 0.508 \\
\hline Nasogastric catheter & $54(48.6)$ & $12(23.5)$ & 0.003 \\
\hline \multicolumn{4}{|l|}{ Concomitant Diseases } \\
\hline Serebrovascular disease & $23(20.7)$ & $3(5.9)$ & 0.017 \\
\hline Chronic obstructive pulmonary disease & $23(20.7)$ & $8(15.7)$ & 0.449 \\
\hline Malignancy & $39(35.1)$ & $24(47)$ & 0.148 \\
\hline Diabetes mellitus & $26(23.4)$ & $12(23.5)$ & 0.988 \\
\hline Chronic renal failure & $14(12.6)$ & $3(5.9)$ & 0.194 \\
\hline Hipertension & $34(30.6)$ & $10(19.6)$ & 0.143 \\
\hline Coronary artery disease & $10(9.0)$ & $3(5.9)$ & 0.496 \\
\hline Heart failure & $8(7.2)$ & $0(0)$ & 0.049 \\
\hline \multicolumn{4}{|l|}{ Previous History of Antibiotic Use } \\
\hline Penicillin & $80(72.1)$ & $36(70.6)$ & 0.846 \\
\hline Cephalosporin & $13(11.7)$ & $8(15.7)$ & 0.484 \\
\hline Quinolon & $13(11.7)$ & $5(9.8)$ & 0.720 \\
\hline Glycopeptid & $39(35.1)$ & $22(43.1)$ & 0.329 \\
\hline Carbapenem & $50(45.1)$ & $23(45.1)$ & 0.995 \\
\hline Macrolide & $32(28.8)$ & $8(15.7)$ & 0.072 \\
\hline \multicolumn{4}{|l|}{ Type of Nutrition } \\
\hline Enteral nutrition & $39(35.1)$ & $13(25.5)$ & 0.222 \\
\hline Total parenteral nutrition (TPN) & $18(16.2)$ & $21(41.2)$ & 0.001 \\
\hline \multicolumn{4}{|l|}{ Others } \\
\hline Hemodialisis & $24(21.6)$ & $10(19.6)$ & 0.770 \\
\hline Use of H2-receptor antagonist & $59(53.2)$ & $21(41.2)$ & 0.157 \\
\hline Immunesuppression & $18(16.2)$ & $12(23.5)$ & 0.266 \\
\hline Blood transfusion & $32(28.8)$ & $23(45.1)$ & 0.042 \\
\hline
\end{tabular}

* Values are expressed as $\mathrm{n}(\%)$. 
Table 6: Independent risk factors for the development of candidemia in cases with Candida infection (Multivariate logistic regression analysis)

\begin{tabular}{|l|c|c|c|}
\hline Variable & p-value & Odds Ratio & \% 95 CI \\
\hline Gender & 0.214 & 1.59 & $0.763-3.338$ \\
\hline Total parenteral nutrition & $\mathbf{0 . 0 0 2}$ & $\mathbf{3 . 6 9}$ & $\mathbf{1 . 5 9 5 - 8 . 5 7 0}$ \\
\hline Blood transfusion & 0.301 & 1.50 & $0,695-3.236$ \\
\hline Nasogastric catheter & 0.044 & 0.42 & $0.182-0.976$ \\
\hline Use of macrolides & 0.778 & 0.86 & $0.327-2.308$ \\
\hline Drainage tube & 0.172 & 1.78 & $0.777-4.107$ \\
\hline Serebrovascular disease & 0.194 & 0.40 & $0.102-1.590$ \\
\hline Heart failure & 0.999 & 0.000 & 0.000 \\
\hline
\end{tabular}

CI: Confidence Interval

\section{DISCUSSION}

In this study, the characteristics of candida infections, species distribution, and antifungal sensitivities results are presented. In our center, the units with the most common infections caused by Candida species were seen to be the anesthesiology intensive care unit (37\%) and the Department of hematology-oncology (19.8\%). The increase of candida infections in these units may be correlated with the follow-up of patients with advanced age group and underlying chronic diseases, the concomitance of immune systemsuppression, invasive applications, and high usage of broad-spectrum antibiotics.

In this study, the isolated species in $66 \%$ of all Candida infections was determined to be $C$. albicans, followed by $C$. glabrata at $9.9 \%, C$. tropicalis at $9.3 \%, C$. parapsilosis at $4.9 \%, C$. lusiteniae at $2.5 \%, C$.krusei at $1.9 \%$ and C. kefyr at $1.2 \%$. The remaining $4.3 \%$ could not be identified on the basis of type. In the Artemis Global Antifungal Surveillance Study by Pfaller et al. ${ }^{9}$, the incidence of $C$. albicans between $1997-$ 2007 was reported as $65.3 \%$, followed by $C$. glabrata (11.3\%), C. tropicalis $(7.2 \%)$ and $C$. parapsilosis (6\%), respectively. Cornistein et al. ${ }^{10}$ detected C. albicans in $43.3 \%, C$. tropicalis in $24.6 \%$ and C. glabrata in $8.1 \%$ of 321 clinical samples. Takakura et al. ${ }^{11}$ found that the rate of $C$. albicans was $40.7 \%$ and C. parapsilosis, 23\%, respectively. In studies from Turkey, Çiçek et al. ${ }^{12}$ reported $C$. albicans at $51.1 \%$ and $C$. tropicalis at $15.8 \%$; Temiz et al. ${ }^{13}$ isolated $C$. albicans at $71 \%, C$. tropicalis and C. glabrata at
8.7\%; and Turhan et al. ${ }^{14}$ isolated C. albicans at $41.9 \%$ and C. parapsilosis at $24.8 \%$. Geographic differences and characteristics of the patient population may result in differences in candida epidemiology, but $C$. albicans remained significant among the Candida species in our center.

Candida-related infections may occur in a broad clinical spectrum. Clinical manifestations may vary due to the type of infection, the respective organ, and the level of immune system suppression $^{15}$. In the study period, the distribution of Candida infections was examined according to systems. UTI was detected in $61.1 \%$, and candidemia was found in $31.5 \%$ of the patients. These infection rates were seen to be similar to those in the literature. In a study by Erdem et al. $^{16}$, the UTI rate was determined as $72.1 \%$, and candidemia rates at $32.9 \%$. In the study made by Hazirolan ${ }^{17}$ reported that the rate of UTI was $56.8 \%$, and the rate of candidemia was $39.4 \%$ in infections caused by Candida isolates. Yang et al. ${ }^{18}$ reported that the rate of UTI was $54.8 \%$, and the rate of candidemia was $30.6 \%$ in 516 fungal infection episodes in intensive care units between 1998 and 2009.

There are difficulties in determining the worldwide rate of candidemia as there is no denominator criterion for the incidence of candidemia. While some countries apply community-based surveillance and use population data as the denominator, other studies have used the duration of disease, discharge, and admission to hospital and intensive care units, resulting in different results of incidence rates of 
candidemia ${ }^{19}$. According to the results of studies which have included various European centers, the candidemia incidence was reported as 0.82.5/1000 hospitalizations ${ }^{20}$, while K1lıç et al. ${ }^{21}$ reported that this rate has increased in recent years. In hospital-based surveillance studies, this rate has been found to be 0.23 per 1000 days of disease (0.06-0.39) in Latin-American countries, 0.15 per 1000 days of disease $(0.01-1.77)$ in a study comprising Asian countries and 0.05 (0.01$0.06)$ per 1000 days of disease in China ${ }^{22}$. In the current study in our center, this rate was 0.11 (0.07-0.19) per 1000 patient days, which was consistent with the literature.

Candidemia is well-defined in specific populations, including hospitalized in surgical departments patients, intensive care unit patients, mechanically ventilated patients, and use of a central venous catheter, indwelling urinary catheter and exposure to total parenteral nutrition ${ }^{20}$. Falcone et al. ${ }^{23}$ reported that the presence of severe sepsis or septic shock, a recent history of a Clostridium difficile infection, concomitance of diabetes mellitus, total parenteral nutrition, chronic obstructive pulmonary disease, concurrent usage of intravenous glycopeptide treatment, a peripherally inserted central catheter and immunosuppressive treatment are all independent risk factors for the development of candidemia. In Turkey, Yapar et al. ${ }^{24}$ reported that a history of taking antibiotics, the use of TPN, blood transfusion, and the presence of urethral catheters were risk factors for the development of candidemia. In the current study, risk factors in patients with candidemia, including TPN, blood transfusion application, the concomitance of cerebrovascular disease, heart failure, male gender, presence of a drainage tube, nasogastric catheter and intubation, and exposure to macrolide group antibiotic were associated with the development of candidemia. According to the multivariate logistic regression analysis, TPN was determined to be statistically significant $(\mathrm{p}=0.002)$ and to be an independent risk factor. The using of TPN increased the risk of candidemia development by 3.69 -fold.

Sensitivity testing has become important in antifungal treatment, with an increase in alterations in distributions and shifts to more resistant isolates in recent years ${ }^{25}$. In a study by Al-Dorzi et al. ${ }^{26}$ investigated the epidemiology and antifungal sensitivity in two different intensive care units in Saudi Arabia, the sensitivity of $C$. albicans species to fluconazole was reported to be $83.3 \%$, and to amphotericin B, 92.9\%. In Non-albicans candida strains, it was reported the sensitivity of $67.9 \%$ to fluconazole and $98.5 \%$ to amphotericin B. In a study made by Posteraro et al. $^{27}$, the sensitivity ratio of $C$. albicans to fluconazole was reported as $99.7 \%$ and the sensitivity ratio of all Candida isolates to amphotericin B was reported as $97 \%$. For the most common four Candida species isolated by Mohamed et al. ${ }^{28}$ in Malaysia the sensitivity to amphotericin B was identified as $100 \%$, while the sensitivity of $C$. albicans to fluconazole was found to be $87.2 \%$. Aydemir et al. ${ }^{29}$ reported resistance to fluconazole of $C$. albicans isolates at $1.1 \%$ and to amphotericin B at $2.1 \%$, while these rates were reported as $7.7 \%$ and $6.4 \%$, respectively for non-albicans Candida strains. Küçükateş et al. ${ }^{30}$ reported that all the detected C.albicans were sensitive to amphotericin B. However, in the same study, the resistance ratio to fluconazole of $C$. albicans was reported as $47.8 \%$. In the current study, the sensitivity of $C$. albicans to fluconazole and amphotericin B was determined as $97.2 \%$ and $99.1 \%$, respectively, and the sensitivity of non-albicans both fluconazole and amphotericin B was determined as $78.2 \%$.

\section{CONCLUSION}

The results of this study demonstrated that $C$. albicans strains are at the forefront of candida infections occurring in our hospital. The application of TPN was seen to be an independent risk factor for the development of candidemia. It is therefore important to determine the distribution of fungal infections in hospitals, especially in ICUs, and to be aware of antifungal sensitivity.

\section{REFERENCES}

1-Eggimann P, Garbino J, Pittet D. Epidemiology of Candida species infections in critically ill nonimmunosuppressed patients. Lancet Infect Dis. 2003 Nov;3(11):685-702.

2-Calandra T, Roberts JA, Antonelli M, Bassetti $\mathrm{M}$, Vincent JL. Diagnosis and management of invasive candidiasis in the ICU: an updated approach to an old enemy. Crit Care. 2016 May 27;20(1):125.

3-Sardi JC, Scorzoni L, Bernardi T, FuscoAlmeida AM, Mendes Giannini MJ. Candida species: Current epidemiology, pathogenicity, biofilm formation, natural antifungal products, and new therapeutic options. J Med Microbiol. 2013 Jan;62(Pt 1):10-24.

4-Arendrup MC, Patterson TF. MultidrugResistant Candida: Epidemiology, Molecular Mechanisms, and Treatment. J Infect Dis. 2017 Aug 15;216(suppl_3):445-51. 
5-Pappas PG, Kauffman CA, Andes DR, Clancy CJ, Marr KA, Ostrosky-Zeichner L, et al. Executive Summary: Clinical Practice Guideline for the Management of Candidiasis: 2016 Update by the Infectious Diseases Society of America. Clin Infect Dis. 2016 Feb 15;62(4):409-17.

6-Delaloye J, Calandra T. Invasive candidiasis as a cause of sepsis in the critically ill patient. Virulence. 2014 Jan 1;5(1):161-9.

7-Cerikcioglu N. Candida Türleri. Enfeksiyon Hastalıkları ve Klinik Mikrobiyolojisi, Editörler: Topcu AW, Söyletir G, Doğanay M. Nobel Tip Kitabevleri, 4.Bask1, Cilt:2, 2017; S: 2115-30.

8-Horan TC, Andrus M, Dudeck MA. CDC/NHSN surveillance definition of healthcare-associated infection and criteria for specific types of infections in the acute care setting. Am J Infect Control. 2008 Jun;36(5):309-32.

9- Pfaller MA, Diekema DJ, Gibbs DL, Newell VA, Ellis D, Tullio V, et al. Global Antifungal Surveillance Group. Results from the ARTEMIS DISK Global Antifungal Surveillance Study, 1997 to 2007: a 10.5-year analysis of susceptibilities of Candida Species to fluconazole and voriconazole as determined by CLSI standardized disk diffusion. J Clin Microbiol. 2010 Apr;48(4):136677.

10- Cornistein W, Mora A, Orellana N, Capparelli FJ, del Castillo M. Candida: epidemiology and risk factors for non-albicans species. Enferm Infecc Microbiol Clin. 2013 Jun-Jul;31(6):380-4.

11-Takakura S, Fujihara N, Saito T, Kudo T, Iinuma $\mathrm{Y}$, Ichiyama S. National surveillance of species distribution in blood isolates of Candida species in Japan and their susceptibility to six antifungal agents including voriconazole and micafungin. J Antimicrob Chemother. 2004 Feb;53(2):283-9.

12-Çiçek B, Yılmaz H, Mutlu Yılmaz E, Esen Ş, Birinci A. Investigation of the changes in Candida epidemiology. Mikrobiyol Bul. 2015 Jul;49(3):423-31.

13-Temiz H, Temiz S, Kaya Ş. Çeşitli Klinik Örneklerden İzole Edilen Kandida Türlerinin Dağılımı ve Antifungal Duyarlılıkları. Okmeydanı T1p Dergisi 2015; 31(1):13-7.

14-Turhan O, Ozhak-Baysan B, Zaragoza O, Er $\mathrm{H}$, Saritas ZE, Ongut G, et al. Evaluation of MALDI-TOF-MS for the Identification of Yeast Isolates Causing Bloodstream Infection. Clin Lab. 2017 Apr 1;63(4):699-703.
15- Vazquez JA. Invasive fungal infections in the intensive care unit. Semin Respir Crit Care Med. 2010 Feb;31(1):79-86.

16-Erdem F, Tuncer EG, Oral B, Karakoç E, Demiröz AP, Tülek N. Candida Türlerine Bağlı Nozokomiyal Enfeksiyonların Epidemiyolojik ve Mikrobiyolojik Açıdan Değerlendirilmesi. Mikrobiyol Bul 2012;46(4):637-48.

17-Hazırolan G. Ankara Numune Eğitim ve Araştırma Hastanesinde hastane enfeksiyonu etkeni olarak izole edilen candida suşlarının dağılımı (2010-2015). Turk Hij Den Biyol Derg. 2018;75 (1): 21-8.

18- Yang SP, Chen YY, Hsu HS, Wang FD, Chen LY, Fung CP. A risk factor analysis of Healthcare-associated fungal infections in an intensive care unit: a retrospective cohort study. BMC Infect Dis. 2013 Jan 9;13:10.

19-Lamoth F, Lockhart SR, Berkow EL, Calandra T. Changes in the epidemiological landscape of invasive candidiasis. J Antimicrob Chemother. 2018 Jan 1;73(suppl_1):i4-i13.

20-Eliakim-Raz N, Babaoff R, Yahav D, Yanai S, Shaked H, Bishara J. Epidemiology, microbiology, clinical characteristics, and outcomes of candidemia in internal medicine wards-a retrospective study. Int J Infect Dis. 2016 Nov;52:49-54.

21- Ulu Kılıç A, Alp E, Cevahir F, Ture Z, Yozgat N. Epidemiology and cost implications of candidemia, a 6-year analysis from a developing country. Mycoses. 2017 Mar;60(3):198-203.

22-Tan BH, Chakrabarti A, Li RY, Patel AK, Watcharananan SP, Liu Z, et al; Asia Fungal Working Group (AFWG). Incidence and species distribution of candidaemia in Asia: a laboratorybased surveillance study. Clin Microbiol Infect. 2015 Oct;21(10):946-53.

23-Falcone M, Tiseo G, Tascini C, Russo A, Sozio E, Raponi G, et al. Assessment of risk factors for candidemia in non-neutropenic patients hospitalized in Internal Medicine wards: A multicenter study. Eur J Intern Med. 2017 Jun;41:33-8.

24-Yapar N, Pullukcu H, Avkan-Oguz V, SayinKutlu S, Ertugrul B, Sacar S. Evaluation of species distribution and risk factors of candidemia: a multicenter case-control study. Med Mycol. 2011 Jan;49(1):26-31.

25- Orasch C, Marchetti O, Garbino J, Schrenzel $\mathrm{J}$, Zimmerli S, Mühlethaler $\mathrm{K}$, FUNGINOS. Candida species distribution and antifungal 
susceptibility testing according to European Committee on Antimicrobial Susceptibility Testing and new vs. old Clinical and Laboratory Standards Institute clinical breakpoints: a 6-year prospective candidaemia survey from the fungal infection network of Switzerland. Clin Microbiol Infect. 2014 Jul;20(7):698-705.

26- Al-Dorzi HM, Sakkijha H, Khan R, Aldabbagh T, Toledo A, Ntinika P, et al. Invasive Candidiasis in Critically Ill Patients: A Prospective Cohort Study in Two Tertiary Care Centers. J Intensive Care Med. 2018 Jan $1: 885066618767835$.

27- Posteraro B, Spanu T, Fiori B, De Maio F, De Carolis E, Giaquinto A, et al. Antifungal susceptibility profiles of bloodstream yeast isolates by Sensititre YeastOne over nine years at a large Italian teaching hospital. Antimicrob Agents Chemother. 2015 Jul;59(7):3944-55.
28-Mohamed NA, Pathmanathan SG, Hussin H, Zaini AB. Distribution and Antifungal Susceptibility Pattern of Candida species at a Tertiary Hospital in Malaysia. J Infect Dev Ctries 2018; 12(2):102-8.

29-Aydemir Ö, Demiray T, Köroğlu M, Aydemir Y, Altındiş M. Emerge of non-albicans Candida species; evaluation of Candida species and antifungal susceptibilities according yo years. Biomed Res. 2017; 28 (6): 2820-25.

30- Kucukates E, Gultekin NN, Alisan Z, Hondur $\mathrm{N}$, Ozturk R. Identification of Candida species and susceptibility testing with Sensititre YeastOne microdilution panel to 9 antifungal agents. Saudi Med J. 2016 Jul;37(7):750-7. 